\title{
Pengaruh Antara Electronic Word of Mouth, Citra Objek Wisata, dan Wisata Halal terhadap Travel Intention melalui Attitude toward Destination
}

(Studi Kasus pada Pengambil Keputusan untuk Wisata Jadetabek)

\author{
Fadlan Fadlullah, Hanny Nurlatifah \\ Program Studi Manajemen Pemasaran, Fakultas Ekonomi dan Bisnis, \\ Universitas Al-Azhar Indonesia, Jalan Sisingamangaraja, Jakarta Selatan 12110,
}

fadlan_11@ymail.com, hanny@uai.ac.id

\begin{abstract}
Abstrak: Tujuan dari penelitian ini adalah untuk mengetahui pengaruh antara Electronic Word of Mouth, Destination Image, dan Halal Islamic Tourism terhadap Travel Intention melalui Attitude Toward Destination. Metode analisis data yang digunakan adalah analisis deskriptif dan analisis jalur (Path Analysis). Populasi dalam penelitian ini adalah pengambil keputusan memilih paket wisata destinasi halal. Sampel dari penelitian ini adalah pengambil keputusan yang berniat melakukan perjalanan dalam kurun waktu 1 tahun terakhir untuk wilayah Jadetabek, sebanyak 103 responden dengan menggunakan metode purposive sampling. Hubungan antara variabel Electronic Word of Mouth, Destination Image, dan Halal Islamic Tourism pada Halal Destination yang memiliki hubungan nyata terhadap variabel Attitude Toward Destination adalah variabel Destination Image. Hubungan antara variabel Electronic Word Of Mouth, Destination Image, Halal Islamic Tourism, dan Attitude Toward Destination terhadap variabel Travel Intention pada Halal Destination yang memiliki hubungan nyata terhadap variabel Travel Intentio adalah variabel Destination Image.
\end{abstract}

Kata Kunci : Electronic Word Of Mouth, Destination Image, Halal Islamic Tourism, Attitude Toward Destination, Travel Intention

Abstract: The purpose of this study was to determine the effect of Electronic Word of Mouth, Destination Image, and Halal Islamic Tourism on Travel Intention through the Attitude Toward Destination. Data analysis methods used are descriptive analysis and path analysis. The population in this study is the decision maker to choose halal destination tourism packages. The sample of this research is the decision makers who intend to travel within the past 1 year for the Jadetabek region, as many as 103 respondents using purposive sampling method. The relationship between Electronic Word of Mouth, Destination Image, and Halal Islamic Tourism variables in Halal Destination that have a real relationship with the Attitude Toward Destination variable is the Destination Image variable. The relationship between Electronic Word of Mouth variables, Destination Image, Halal Islamic Tourism, and Attitude Toward Destination to the Travel Intention variable at Halal Destination that has a real relationship to the Travel Intentio variable is the Destination Image variable.

Keywords: Electronic Word Of Mouth, Destination Image, Halal Islamic Tourism, Attitude Toward Destination, Travel Intention 


\section{Pendahuluan}

Sektor pariwisata di seluruh dunia baru-baru ini sadar akan potensi besar dari pasar wisata Islam, dan dengan pelabelan halal menjadi lebih umum, konsumen Muslim diuntungkan dari meningkatnya peluang dan fasilitas wisata yang memenuhi kebutuhan spesifik mereka dan dengan demikian dapat menikmati semacam waktu luang dan liburan yang dianggap sebagai bagian penting dari kehidupan modern. Dengan meningkatnya daya beli wisatawan Muslim, tren yang berkembang paling pesat dalam pariwisata halal menarik banyak pemasar (Battour, Battor \& Ismail, 2012).

Konsep pariwisata halal belakangan ini sudah banyak diketahui oleh masyarakat muslim yang menginginkan wisata dengan tidak melanggar apa yang dianjurkan dalam agama islam. Pariwisata halal mengacu pada kegiatan yang dilakukan oleh para wisatawan muslim dengan berpergian dengan merasa tenang tanpa takut melanggar dari ajaran agama islam. Hal seperti makanan, tempat wisata, ketersediaan tempat beribadah adalah beberapa hal yang harus diperhatikan bagi wisatawan muslim yang ingin melakukan perjalanan wisatanya.

Seiring dengan berkembangnya tehnologi, membuat masyrakat semakin percaya pada hal hal yang berasal dari internet. Begitu juga dengan pengambilan keputusan konsumen yang telah dipercaya oleh EWOM dari konsumen lain yang telah merasakannya lebih dulu. Ulasan yang diberikan konsumen lain sering dianggap oleh pembaca sebagai berita terkini dan dapat diandalkan dari pada hanya sekedar informasi yang diberikan oleh perusahaan penyedia layanan wisata.

Persepsi Destination Image terkait dengan branding tujuan, yang dapat membuktikan menjadi tugas yang sangat kompleks mengingat bahwa destinasi seperti kota adalah entitas yang memiliki banyaksegi dan mau tak mau berarti hal yang berbeda bagi konsumen yang berbeda (Ashworth \& Kavaratzis, 2009; Ashworth \& Page, 2011).

Attitude dari seseorang tentang suatu hal, merupakan ungkapan dari suatu hal yang sedang dialami apakah menyenangkan ataupun tidak menyengkan yang akan mempengaruhi perilaku dari orang tersebut. Dalam memilih suatu destinasi wisata seseorang juga sangat dipengaruhi oleh Attitude yang akan diungkapkan dari destinasi wisata yang akan dipilih oleh calon konsumen.
Travel Intention, seseorang yang berniat melakukan suatu perjalanan tertentu. Motivasi dalam melakukan niat perjalanan sangat berpengaruh besar dalam pengambilan keputusan apakah akan melakukan perjalanan atau tidak. Niat perjalanan dengan motivasi yang positif akan berdampak besar bagi seseorang untuk melakukan suatu perjalanan.

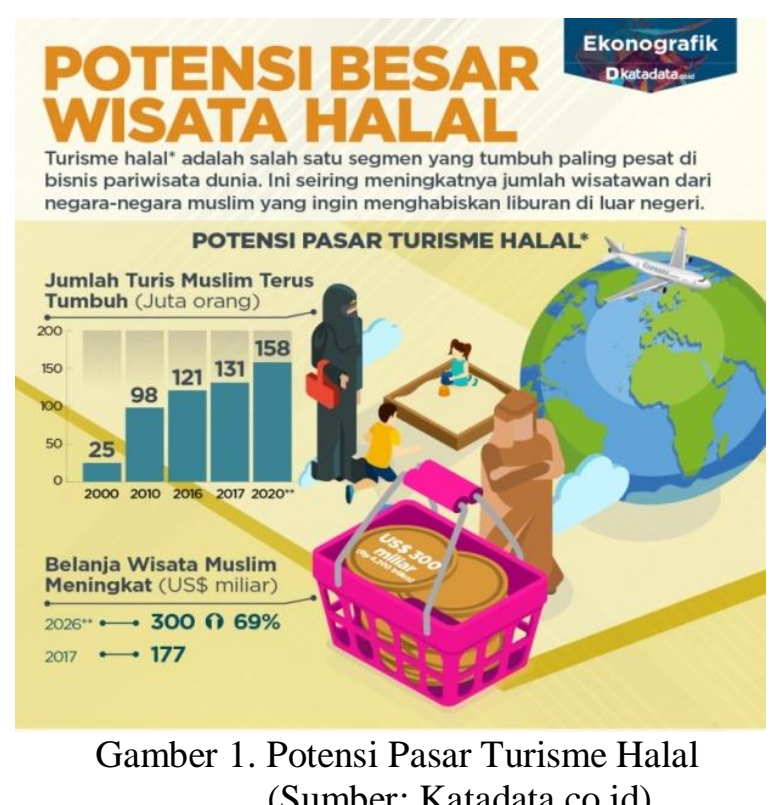

Dari data diatas dapat dilihat bahwa tingginya potensi pasar turisme halal terlihat dari jumlah wisatawan yang terus meningkat, data yang dihimpun Global Muslim Travel Index 2018 (GMTI) menunjukkan jumlah wisatawan muslim diperkirakan mencapai 158 juta orang pada 2020. Angka itu tumbuh 21 persen dibandingkan jumlah wisatawan pada 2017. Jumlah tersebut di luar ibadah haji dan umrah.

Data menurut Bank Indonesia juga menunjukkan jumlah outbound wisatawan Indonesia mencapai 5,2 juta atau tumbuh $10 \%$ pada semester 2019 di bandingkan dari periode yang sama tahun lalu berjumlah 4,73 juta wisatawan (https://ekonomi.bisnis.com) yang menandakan kemungkinan wisatawan yang ingin berwisata ke tempat destinasi halal di luar negeri semakin meningkat.

Data menurut HTK (Halal Travel Konsorsium) (https://travel.detik.com/travel-news) sekitar 20 juta pelancong muslim Indonesia yang bepergian ke luar negeri pada 2019. Dengan semakin meningkatnya turis muslim yang melakukan 
perjalanan ke luar negeri membuat masyrakat di Indonesia yang rela melakukan pengeluaran keuangannya untuk berwisata ke luar negeri menuju destinasi wisata halal. Jika dicermati masyarakat muslim Indonesia banyak yang ingin menghabiskan liburan dengan berwisata halal di luar negeri.

Berdasarkan penjelasan yang telah terurai diatas mengenai beberapa literature yang membahas tentang variabel Electronic Word of Mouth, Destination Image, Halal Islamic Tourism, Attitude Toward Destination, Religious Orientation, dan Travel Intention.

\section{Tinjauan Pustaka}

\section{Electronic Word of Mouth}

Electronic Word of Mouth merupakan bentuk komunikasi non-formal yang sebagian diarahkan pada pelanggan melalui teknologi berbasis internet yang berkaitan dengan penggunaan atau karakteristik suatu barang atau jasa (Litvin et al., dalam Abd-elaziz et al., 2015).

Electronic Word of Mouth merupakan komunikasi pemasaran yang dilakukan secara online melalui media sosial internet (Schiffman dan Kanuk dalam Haekal, 2016:27). Pengembangan konten yang dibuat pengguna melalui blog, Wikipedia, dan jejaring sosial Situs telah memberikan manajemen media tambahan kepada pelanggan yang mengambil peran aktif dalam situs pilihan pembelian mereka (Chu dan Kim, 2011). Ulasan online tidak hanya membuat pengambilan keputusan lebih mudah bagi konsumen dengan mengurangi beban kognitif tetapi juga secara simultan membantu dalam meningkatkan penjualan (Ye et al., 2011).

Dengan semakin populernya situs jejaring sosial, seiring perkembangan teknologi interaktif, EWOM tidak hanya terbatas pada pernyataan pelanggan sendiri tetapi juga harus merangkul posting dari pengecer atau sumber lain yang diterbitkan, yang dibagikan atau dikirim ulang oleh potensi, pelanggan saat ini atau sebelumnya tentang suatu produk atau merek (Hu et al., 2014). EWOM sosial terjadi ketika konsumen memberikan atau mengeksplorasi rekomendasi terkait produk informal melalui aplikasi sosial yang khas situs jaringan. Semakin populernya jaringan penyiaran sosial seperti Facebook dan Twitter telah mengubah cara WOM online disebarluaskan dan dikonsumsi di era digital internet (Rui et al., 2013).
Menurut Bambauer-Sachse and Mangold (2011), Electronic Word of Mouth dapat diukur melalui enam item sebagai berikut:

1. Receiver's Awareness, berkonsultasi dengan konsumen lain secara online mengenai ulasan produk untuk membantu memilih produk /merek.

2. Attention, ketika membeli produk / merek, ulasan produk konsumen online membuat percaya diri untuk membeli produk / merek

3. Consideration, mengumpulkan informasi dari ulasan produk konsumen online sebelum membeli produk / merek tertentu.

4. Brand attitudes, membaca ulasan produk dari konsumen online lainnya untuk mengetahui produk / merek apa membuat kesan yang baik kepada orang lain.

5. Intentions, jika tidak membaca ulasan produk online konsumen ketika membeli sebuah produk / merek, akan khawatir mengenai keputusannya

6. Expectations, untuk memastikan memilih produk / merek yang tepat, dengan sering membaca ulasan online konsumen lainnya.

\section{Destination Image}

Menurut Lawson dan Bovy dalam Utama (2016:169) Citra Destinasi adalah sebuah ekspresi tentang sebuah pengetahuan, keyakinan diri, prasangka, hayalan dan pikiran emosional seorang individu tentang objek atau tempat tertentu. Sedangkan Pitana dan Gayatri dalam Akbar dan Edrina (2017:156) berpendapat bahwa setiap daerah tujuan wisata mempunyai citra tertentu, yakni mental maps seseorang terhadap suatu destinasi pariwisata yang mengandung keyakinan, kesan, dan persepsi. Untuk meningkatkan daya saing tempat dan meningkatkan loyalitas pengunjung, pemahaman mendalam tentang proses pembentukan gambar tujuan dan karakteristiknya diperlukan (Qu, Kim dan Im, 2011).

Kesan yang menguntungkan dari tujuan wisata dalam pikiran pengunjung memicu kecenderungan positif, yang memotivasi pengunjung untuk mengalami keaslian dan secara positif mempersepsikan keaslian dari pengalaman (Jiang et al., 2015). Menurut Hanif et. al., (2010) bahwa Citra Destinasi (Destination Image) merupakan keyakinan/pengetahuan mengenai suatu destinasi dan apa yang dirasakan oleh wisatawan selama berwisata. 
Destination Image Menurut Gartner dalam Wibisono dan Yahya (2016:74) terbagi dalam tiga kategori, sebagai berikut :

1. Kognitif, merupakan komponen berhubungan dengan pengetahuan dan kepercayaan tentang destinasi wisata yang berasal dari sumbersumber informasi yang diperoleh wisatawan melalui berbagai atribut destinasi wisata seperti fasilitas akomodasi, atraksi wisata, dan kemudahan akses masuk ke destinasi wisata.

2. Afektif, merupakan komponen yang berhubungan dengan perasaan yang kuat dari wisatawan terhadap atribut destinasi, dan merupakan salah satu faktor yang berpengaruh didalam melihat destinasi wisata apakah destinasi wisata itu menyenangkan atau tidak menyenangkan sehingga mereka bisa memutuskan untuk mengunjungi tempat wisata atau tidak.

3. Konatif, merupakan komponen yang berhubungan dengan perilaku wisatawan yang menggambarkan mental dan proses dari hasil interaksi kognitif dan afektif dan merupakan tindakan untuk melakukan kunjungan ke tempat wisata dalam suatu periode waktu tertentu.

\section{Islamic Halal tourism}

Halal Tourism Islamic adalah "segala objek atau tindakan wisata yang diizinkan menurut ajaran Islam untuk digunakan atau dilibatkan oleh umat Islam dalam Industri pariwisata" (Battour \& Ismail, 2016, p. 2). Mohsin, Ramli, dan Alkhulayfi (2016) berpendapat bahwa Halal Tourism Islamic adalah jenis pariwisata yang menganut nilai Islam. Wisata halal berkaitan dengan objek wisata atau kegiatan yang cocok untuk wisatawan Muslim.

El-Gohary (2016) menegaskan bahwa rujukan pariwisata halal untuk menawarkan paket wisata yang sejalan dengan hukum Islam atau Syariah. Dia menegaskan bahwa halal pariwisata mungkin berurusan dengan hotel halal, makanan halal, halal logistik dan kegiatan keuangan Halal (mis. Menggunakan Bank syariah untuk transaksi). Selain itu, El-Gohary (2016) mengatakan beberapa kunci lainnya atribut pariwisata halal berkaitan dengan kegiatan dan produk berdasarkan konsep Islam.

Menurut Battour dan Ismail (2014), terdapat empat atribut untuk mengukur Halal Tourism Islamic menggunakan dimensi sebagai berikut:
1. Islamic Facilities, fasilitas ibadah seperti masjid, arah kiblat dan fasilitas wudhu (wudhu), adalah elemen penting bagi wisatawan Muslim ketika mereka sedang berlibur.

2. Halalness, mengacu pada fasilitas Halal, seperti dapur, alat pemotong, dan makanan halal.

3. General Islamic Morality, mengacu pada aturan umum dalam Islam seperti aturan berpakaian, pelarangan pelacuran, dan penyensoran adegan seks di TV.

4. free alcohol drinks and gambling, peraturan tentang minuman alkohol dan bebas dari perjudian.

\section{Attitude toward Destination}

Sikap, yang merupakan ringkasan evaluatif yang relatif permanen dan stabil tentang suatu item, adalah konstruksi psikologis yang penting karena itu telah ditemukan berdampak dan memprediksi banyak perilaku (Kraus, 1995 dalam Jalilvand dan Samei, 2012). Sikap terhadap destinasi menekankan pada perilaku wisatawan, sikap wisatawan menggambarkan kecenderungan psikologis yang diungkapkan oleh evaluasi wisatawan positif atau negatif ketika terlibat dalam perilaku tertentu (Ajzen, 1991; Schiffman dan Kanuk, 1994; Kraus, 1995 di Jalilvand dan Samei 2012).

Sikap mengacu pada evaluasi keseluruhan seseorang dalam melakukan perilaku. Beberapa penelitian telah menunjukkan bahwa niat itu ditentukan oleh sikap terhadap perilaku. Sikap terhadap perilaku telah didefinisikan sebagai sejauh mana seseorang memiliki evaluasi atau penilaian yang menguntungkan atau tidak menguntungkan perilaku dalam pertanyaan. Secara umum, semakin menguntungkan sikap terhadap perilaku, semakin kuat akan menjadi niat individu untuk mengadopsi perilaku (Zarrad dan Debabi, 2015).

Menurut Gamble, Juliusson, and Garling (2009) Attitude toward Destination dapat diukur menggunakan item sebagai berikut:

Sebagai tujuan wisata, saya pikir destinasi $\mathrm{x}$ adalah:

1. Sangat buruk / sangat baik.

2. Sangat tidak berharga / sangat berharga.

3. Sangat tidak menyenangkan/ sangat menyenangkan.

\section{Travel Intention}


Minat berkunjung sebenarnya sebuah pengaplikasian dari minat beli sutatu produk. Maka minat berkunjung pada dasarnya merupakan sebuah perasaan keinginan untuk mengunjungi atau mendatangi tempat-tempat yang menurut mereka menarik untuk dikunjungi (Putra, Gagah Bimo Setyo., Kumadji, Srikandi, dan Hidayat, 2015). Minat berkunjung yang merupakan suatu keinginan dari konsumen untuk memenuhi kebutuhan dan keinginan yang tersembunyi dalam pihak konsumen. Para konsumen sebelum melakukan pembelian atau menentukan keputusan akan mencari informasi mengenai produk atau jasa tersebut yang akhirnya menciptakan minat berkunjung (Laksmini et. al., 2016). Adanya keinginan untuk mengunjungi suatu tempat destinasi atau wisata dengan melakukan survey melalui media sosial. Dengan mengulas berbagai ulasan di dalam internet untuk melihat review jumlah pengunjung yang dating untuk menarik perhatian para calon pengunjungnya (Laksmini et. al., 2016).

Menurut Kassem et al. (2010) Travel Intention dapat diukur menggunakan item sebagai berikut:

1. Saya memperkirakan saya akan mengunjungi ... di masa depan.

2. Saya akan mengunjungi ... dari pada tujuan wisata lainnya.

3. Jika semuanya berjalan seperti yang saya pikirkan, saya akan berencana untuk mengunjungi ... di masa depan.

\section{Metode Penelitian}

Populasi dalam penelitian ini adalah pengambil keputusan memilih paket wisata destinasi halal di wilayah Jadetabek.

Dalam istilah penelitian kuantitatif, objek penelitian yang kecil ini disebut sebagai sampel total, yaitu keseluruhan populasi merangkap sebagai sampel penelitian. Sampel dari penelitian ini adalah pengambil keputusan memilih paket wisata destinasi halal yang berniat melakukan perjalanan dalam kurun waktu 1 tahun terakhir untuk wilayah Jadetabek. Untuk itu penelitian ini diperlukan sekitar 100 responden yang didapat dari rumus perhitungan sampel dengan proporsi penduga.

Pada penelitian ini populasi yang diambil berukuran besar dan jumlahnya tidak diketahui secara pasti. Dalam penentuan sampel jika populasinya besar dan jumlahnya tidak diketahui secara pasti menurut Widiyanto (2008) menggunakan rumus non-probabillity sampling dengan cara Purposive Sampling. Teknik Non Probability Sampling adalah teknik pengambilan sampel yang tidak memberi kesempatan atau peluang yang sama untuk dipilih menjadi sampel. Purposive sampling adalah teknik penarikan sampel yang dilakukan berdasarkan

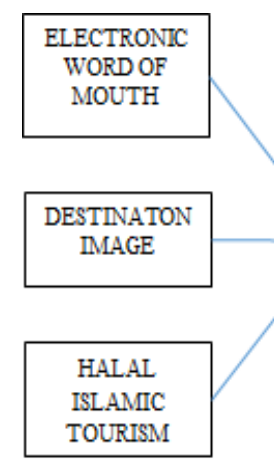

Gambar 2. Kerangka Penelitian

kara

kteri

stik yang ditetapkan terhadap elemen populasi target yang disesuaikan dengan tujuan atau masalah penelitian.

Tabel 1. Variabel Penelitian

\begin{tabular}{|c|l|}
\hline \multicolumn{2}{|c|}{$\begin{array}{c}\text { Electronic Word of Mouth Communication } \\
\text { Zarrad H. \& Debabi M., 2015) }\end{array}$} \\
\hline $\begin{array}{c}\text { Receiver's } \\
\text { Awareness }\end{array}$ & $\begin{array}{l}\text { Berkonsultasi dengan konsumen lain } \\
\text { secara online mengenai ulasan } \\
\text { produk untuk membantu memilih } \\
\text { produk /merek }\end{array}$ \\
\hline Attention & $\begin{array}{l}\text { Membaca ulasan dari produk } \\
\text { konsumen online lainnya }\end{array}$ \\
\hline Consideration & $\begin{array}{l}\text { Membaca ulasan produk dari } \\
\text { konsumen online lainnya untuk } \\
\text { mengetahui produk / merek apa } \\
\text { membuat kesan yang baik kepada } \\
\text { orang lain. }\end{array}$ \\
\hline Brand & $\begin{array}{l}\text { Mengumpulkan informasi dari } \\
\text { ulasan produk konsumen online } \\
\text { sebelum membeli produk / merek } \\
\text { tertentu. }\end{array}$ \\
\hline Intentions & $\begin{array}{l}\text { Jika tidak membaca ulasan produk } \\
\text { online konsumen ketika membeli } \\
\text { sebuah produk / merek, Akan } \\
\text { khawatir mengenai keputusannya }\end{array}$ \\
\hline Expectattions & $\begin{array}{l}\text { Ketika membeli produk / merek, } \\
\text { ulasan produk konsumen online } \\
\text { membuat percaya diri untuk } \\
\text { membeli produk / merek }\end{array}$ \\
\hline Services, & $\begin{array}{l}\text { Destination Image } \\
\text { a.Suasana dan gaya hidup yang unik } \\
\text { b.Kota sebagai tujuan terkenal }\end{array}$ \\
\hline
\end{tabular}




\begin{tabular}{|c|c|}
\hline $\begin{array}{c}\text { and } \\
\text { Atmosphere }\end{array}$ & $\begin{array}{l}\text { c.Nilai uang yang baik } \\
\text { d.Akomodasi yang cocok } \\
\text { e.Menawarkan penghibur yang baik } \\
\text { f.Menawarkan makanan lokal yang } \\
\text { menarik } \\
\text { g.Kota yang bersih dan terawat } \\
\text { dengan baik } \\
\text { h.Orang-orang lokal yang ramah } \\
\text { i.Menawarkan pilihan untuk } \\
\text { keluarga dan anak-anak } \\
\text { j.Kota yang mudah diakses oleh para } \\
\text { wisatawan }\end{array}$ \\
\hline $\begin{array}{l}\text { Unique City } \\
\text { Attractions }\end{array}$ & $\begin{array}{l}\text { a.Objek wisata sejarah signifikan } \\
\text { b.Atraksi keagamaan yang } \\
\text { signifikan } \\
\text { c.Pemandangan indah / wisata alam } \\
\text { d.Arsitektur yang dibangun menarik }\end{array}$ \\
\hline $\begin{array}{l}\text { Activities and } \\
\text { Events }\end{array}$ & $\begin{array}{l}\text { a.Kegiatan dan acara budaya } \\
\text { b.Kegiatan dan konferensi bisnis } \\
\text { c.Kegiatan rekreasi dan olahraga }\end{array}$ \\
\hline Affective & $\begin{array}{l}\text { a.Tidak menyenangkan } \\
\text { menyenangkan } \\
\text { b.Menyedihkan / santai } \\
\text { c.Buruk / cantik } \\
\text { d.Suram / menyenangkan } \\
\end{array}$ \\
\hline$(\mathrm{Wa}$ & $\begin{array}{l}\text { Halal Tourism Islamic } \\
\text { di, Abror, Trinanda, (2018) }\end{array}$ \\
\hline $\begin{array}{l}\text { Islamic } \\
\text { Facilities }\end{array}$ & $\begin{array}{l}\text { a.Ketersediaan fasilitas ibadah di } \\
\text { lokasi wisata } \\
\text { b.Kehadiran pengumuman publik } \\
\text { yang keras tentang Azan untuk } \\
\text { menunjukkan waktu sholat }\end{array}$ \\
\hline $\begin{array}{l}\quad \text { Halalness } \\
\text { - Halal Foods } \\
\text { - Kitchen }\end{array}$ & $\begin{array}{l}\text { a.Ketersediaan makanan halal di } \\
\text { lokasi wisata, mal, hotel, dll } \\
\text { b.Ketersediaan dapur halal terpisah } \\
\text { di hotel dan restoran }\end{array}$ \\
\hline $\begin{array}{l}\text { General } \\
\text { Islamic } \\
\text { Moralty }\end{array}$ & $\begin{array}{l}\text { a.Larangan oleh } \\
\text { menampilkan tidak senonoh kasih } \\
\text { sayang antara jenis kelamin di } \\
\text { tempat umum (seperti berciuman } \\
\text { dll.) } \\
\text { b.Larangan saluran seks dalam } \\
\text { sistem hiburan hotel } \\
\text { c.Larangan pelacuran dari otoritas } \\
\text { d.Sensor oleh otoritas adegan } \\
\text { dewasa dalam film yang } \\
\text { ditayangkan di TV }\end{array}$ \\
\hline $\begin{array}{l}\text { Regulation } \\
\text { for Alcohol } \\
\text { and } \\
\text { Gambling } \\
\text { Free }\end{array}$ & $\begin{array}{l}\text { a.Larangan minuman beralkohol } \\
\text { oleh otoritas di tempat-tempat umum } \\
\text { (seperti pariwisata situs, hotel, } \\
\text { taman, dll.) } \\
\text { b.Larangan kegiatan perjudian oleh } \\
\text { otoritas di tempat-tempat umum } \\
\text { (seperti situs pariwisata, hotel, } \\
\text { taman, dll.) }\end{array}$ \\
\hline \multicolumn{2}{|c|}{$\begin{array}{l}\text { Attidtude Toward Destination } \\
\text { (Zarrad H. and Debabi M., 2015) }\end{array}$} \\
\hline
\end{tabular}

\begin{tabular}{|c|l|}
\hline $\begin{array}{c}\text { Attidtude } \\
\text { Toward } \\
\text { Destination }\end{array}$ & $\begin{array}{l}\text { Sebagai tujuan wisata, saya pikir } \\
\text { wisata halal adalah: } \\
\text { a.sangat buruk / sangat bagus } \\
\text { b.sangat tidak berharga/sangat } \\
\text { berharga } \\
\text { c.sangat tidak menyenangkan / } \\
\text { sangat menyenangkan }\end{array}$ \\
\hline \multicolumn{3}{|c|}{ Travel Intention } \\
(Jalilvand, Ebrahimi, Samiei, 2012)
\end{tabular}

\section{Hasil dan Pembahasan}

\section{Analisis Deskriptif}

Tabel 2 dan 3 menampilkan deskripsi responden hasil pengumpulan data.

Tabel 2. Karakteristik Demografi

\begin{tabular}{clcc}
\hline $\begin{array}{c}\text { Pertanya } \\
\text { an }\end{array}$ & \multicolumn{1}{c}{ Item } & $\begin{array}{c}\text { Frekuen } \\
\text { si }\end{array}$ & $\begin{array}{c}\text { Presenta } \\
\text { se }\end{array}$ \\
\hline Jenis & Wanita & 48 & $46,6 \%$ \\
Kelamin & PRIA & 55 & $53,4 \%$ \\
& TOTAL & 103 & $100 \%$ \\
\hline & $17-20$ Tahun & 0 & $0 \%$ \\
& $21-25$ & & \\
& TAHUN & 29 & $28,2 \%$ \\
& 26-29 & & \\
& TAHUN & 5 & $4,9 \%$ \\
& 30 - 39 & & \\
Usia & TAHUN & 25 & $24,3 \%$ \\
& 40 - 49 & & \\
& TAHUN & 32 & $31,1 \%$ \\
& 50 - 54 & & \\
& TAHUN & 11 & $10,7 \%$ \\
& $>55$ TAHUN & 1 & $1 \%$ \\
& TOTAL & 103 & $100 \%$ \\
\hline \multirow{5}{*}{ Pendidika } & Smp & 0 & $0 \%$ \\
& SMA/SEDERA & & \\
JAT & 31 & $30,1 \%$ \\
& DIPLOMAT & 13 & $12,6 \%$ \\
& SARJANA & 56 & $54,4 \%$ \\
& S2/S3 & 3 & $2,9 \%$ \\
& TOTAL & 103 & $100 \%$ \\
\hline \multirow{5}{*}{ Profesi } & Mahasiswa & 22 & $21,4 \%$ \\
& Ibu rumah & & \\
& tangga & 12 & $11,7 \%$ \\
& Wiraswasta & 1 & $1 \%$ \\
& Karyawan & & \\
& swasta & 21 & $20,4 \%$ \\
& PNS & 26 & $25,2 \%$ \\
& Lainnya & 21 & $20,4 \%$ \\
& & &
\end{tabular}




\begin{tabular}{clcc} 
& \multicolumn{1}{c}{ TOTAL } & 103 & $100 \%$ \\
\hline & $\begin{array}{l}7.000 .000- \\
11.000 .000\end{array}$ & 31 & $30,1 \%$ \\
Pengeluar & $\begin{array}{l} \\
2.800 .000-\end{array}$ & & \\
an & 4.250 .000 & 36 & $35 \%$ \\
Perbulan & $1.400 .000-$ & & \\
Diluar & 2.800 .000 & 11 & $10,7 \%$ \\
Cicilan & $<1.400 .000$ & 25 & $24,3 \%$ \\
& $\quad$ TOTAL & 103 & $100 \%$ \\
\hline \multirow{3}{*}{ Ktatus } & Kepala & & \\
Kalam & ANGGOTA & 46 & $44,7 \%$ \\
Keluarga & KELUARGA & 57 & $55,3 \%$ \\
& $\quad$ TOTAL & 103 & $100 \%$ \\
\hline
\end{tabular}

Sumber: Data Primer (Diolah penulis, 2019)

Tabel 3. Perilaku Berbelanja

\begin{tabular}{|c|c|c|c|}
\hline $\begin{array}{c}\text { Perilaku } \\
\text { Belanja }\end{array}$ & Keterangan & Jumlah & $\begin{array}{c}\text { Presenta } \\
\text { se }\end{array}$ \\
\hline & Saudi Arabia & 6 & $5,8 \%$ \\
\hline & TURKEY & 17 & $16,5 \%$ \\
\hline & UNI EMIRATE & & \\
\hline Negara & ARAB & 5 & $4,9 \%$ \\
\hline yang ingin & RUSSIA & 0 & $0 \%$ \\
\hline dikunjung & SINGAPORE & 15 & $14,6 \%$ \\
\hline i dalam 1 & SPANYOL & 1 & $1 \%$ \\
\hline tahun & PRANCIS & 9 & $8,7 \%$ \\
\hline \multirow[t]{5}{*}{ terakhir } & THAILAND & 11 & 10,7 \\
\hline & BELUM ADA & & \\
\hline & RENCANA & 11 & $10,7 \%$ \\
\hline & LAINNYA & 14 & $13,6 \%$ \\
\hline & TOTAL & 103 & $100 \%$ \\
\hline Yang & Keluarga & 39 & $37,9 \%$ \\
\hline Menganju & TEMAN & 18 & $17,5 \%$ \\
\hline rkan & DIRI SENDIRI & 40 & $38,8 \%$ \\
\hline Memilih & LAINNYA & 6 & $5,8 \%$ \\
\hline \multicolumn{4}{|l|}{ Destinasi } \\
\hline \multirow[t]{3}{*}{ Wisata } & TOTAL & 103 & $100 \%$ \\
\hline & Berbelanja & 24 & $23,3 \%$ \\
\hline & KULINER & 20 & $19,4 \%$ \\
\hline Kegiatan & MENYAKSIK & & \\
\hline Yang & AN ATRAKSI & 24 & $23,3 \%$ \\
\hline Biasa & MENGUNJUN & & \\
\hline Dilakukan & GI & & \\
\hline Saat & BANGUNAN & 17 & $16,5 \%$ \\
\hline \multirow[t]{4}{*}{ Berwisata } & BERSEJARAH & & \\
\hline & LAINNYA & 18 & $17,5 \%$ \\
\hline & TOTAL & 103 & $100 \%$ \\
\hline & $1-2$ Kali & 69 & $67 \%$ \\
\hline Intensitas & 3 - 5 KALI & 20 & $19,4 \%$ \\
\hline Berwisata & $6-8 \mathrm{KALI}$ & 1 & $1 \%$ \\
\hline Ke Luar & $>8$ KALI & 0 & $0 \%$ \\
\hline \multirow[t]{2}{*}{ Negeri } & Belum pernah & 13 & $12,6 \%$ \\
\hline & TOTAL & 103 & $100 \%$ \\
\hline Cara & Travel Agent & 34 & $33 \%$ \\
\hline Untuk & MENYUSUN & & \\
\hline Berwisata & SENDIRI & 65 & $63,1 \%$ \\
\hline Ke Luar & LAINNYA & 4 & $3,9 \%$ \\
\hline
\end{tabular}

\begin{tabular}{cccc} 
Negeri & T OTAL & 103 & $100 \%$ \\
\hline Sumber: Data Primer (Diolah penulis, 2019)
\end{tabular}

\section{Analisis Jalur}



Hipotesis Penelitian:

H1: EWOM berpengaruh terhadap Attitude toward Destination.

H2: Destination Image berpengaruh terhadap Attitude toward Destination.

H3: Halal Islamic Tourism tidak berpengaruh terhadap Attitude toward Destination.

H4: EWOM tidak berpengaruh terhadap Travel Intention.

Gambar 3. Hasil analisa jalur

H5: Destination Image berpengaruh terhadap Travel Intention.

H6: Halal Islamic Tourism tidak berpengaruh terhadap Travel Intention.

H7: Attitude toward Destination berpengaruh terhadap Travel Intention.

Variabel Electronic Word of Mouth, Destination Image dan Halal Islamic Tourism terhadap Attitude Toward Destination diolah dengan menggunakan analisis jalur, kemudian menghasilkan hanya variabel Destination Image dalam perhitungan IBM SPSS menunjukan t tabel penelitian 2.335 yang dimana lebih besar dari pada 2,042, maka keputusannya adalah HO ditolak dan Hi diterima, artinya adanya hubungan linear pada variabel tersebut. Karena adanya hubungan linear pada variabel tersebut, maka Destination Image mempengaruhi kepada Attitude Toward Destination. Besarnya pengaruh Destination Image 
terhadap variabel Attitude Toward Destination dapat diketahui dari nilai koefisien beta yaitu sebesar 0.256 Pengaruh ini berpengaruh tidak signifikan karena nilai signifikasi dari hasil perhitungan tertera $0,022>0.05$. Sedangkan variabel Electronic Word of Mouth dan Halal Islamic Tourism telah dikeluarkan karena tidak signifikan.

Hubungan langsung antar variabel Destination Image dengan Travel Intention dan juga terdapat hubungan tidak langsung antar variabel Destination Image terhadap Travel Intention melalui Attitude Toward Destination sebagai intervening. Berdasarkan hasil dari penelitian tersebut, hubungan langsung mempengaruhi Travel Intention adalah hubungan langsung antar variabel Destination Image dengan Travel Intention karena nilai hubungannya $0,256>0,062486$ yaitu nilai hubungan tidak langsung.

Gambar 3. Hasil pengolahan data

Berdasarkan penelitian yang telah dilakukan, dapat dilihat bahwa niat mengunjungi Halal Travel Destination dalam kurun waktu 1 tahun terakhir menunjukkan bahwa sebagian besar pengambil keputusan dipengaruhi oleh bagaimana citra destinasi dari Halal Travel Destination. Pengambil keputusan lebih mementingkan citra destinasi dibanding memperhatikan dari EWOM (jaringan sosial dalam bentuk komunitas virtual online) dan faktor dari pariwisata halal. Pengambil keputusan melihat bahwa citra destinasi dari Halal Travel Destination sebagai acuan apakah citra tersebut besifat positif atau tidak untuk mengambil keputusan dalam melakukan niat mengunjungi tempat destinasi wisata halal. Maka dari itu, penelitian ini bertolak belakang dengan penelitian yang dilakukan oleh Zarrad H. dan Debabi M. (2015) yang berjudul (Analyzing the Effect of Electronic Word of Mouth on Tourists' attitude toward Destination and Travel Intention) yang menyatakan bahwa EWOM dan Attitude Toward Destination berperan penting mempengaruhi calon konsumen untuk mengunjungi suatu destinasi wisata halal. Namun penelitian ini signifikan dengan penelitian yang telah dilakukan oleh YingChan Liu, I-Jing Li, Shang-Yun Yen, Peter J. Sher (2018) yang berjudul (What Makes Muslim Friendly Tourism? An Empirical Study on Destination Image, Tourist Attitude and Travel Intention) yang menyatakan bahwa Destination Image memiliki dampak positif terhadap konsumen yang akan berniat mengunjungi destinasi wisata halal.

\section{Kesimpulan dan Saran}

\section{Kesimpulan}

Berdasarkan hasil analisis data dan pembahasan dapat di ambil kesimpulan sebagai berikut.

1. Responden dalam penelitian ini merupakan pengambil keputusan memilih paket wisata destinasi halal yang berniat melakukan perjalanan dalam kurun waktu 1 tahun terakhir. Dengan jumlah responden yaitu 103 responden, jenis kelamin responden dalam penelitian ini lebih banyak pria berjumlah 55 orang, usia responden dalam penelitian ini lebih banyak berusia 40-49 tahun berjumlah 32 orang, pendidikan terakhir responden penelitian ini paling banyak berpendidikan terakhir sarjana berjumlah 56 orang, pekerjaan responden dalam penelitian ini lebih banyak yang berprofesi sebagai pegawai negeri berjumlah 26 orang, dan pengeluaran perbulan diluar cicilan terbanyak yang dikeluarkan oleh responden berpengeluaran $\mathrm{Rp} 2.800 .000$ sampai $\mathrm{Rp}$. 4.250 .000 sebanyak 36 orang.

2. Tidak adanya pengaruh Halal Islamic Tourism, adanya pengaruh Electronic Word of Mouth dan Destination Image terhadap Attidtude Toward Destination Halal Travel Destination. Adanya pengaruh Destination Image, dan tidak adanya pengaruh Electronic Word of Mouth dan Halal Islamic Tourism melalui Attidtude Toward Destination terhadap Travel Intention Halal Travel Destination.

\section{Saran}

1. Untuk Halal Travel Destination disarankan untuk lebih meningkatkan Electronic Word of Mouth dan Halal Tourism Islamic tidak hanya mengutamakan citra destinasi saja tetapi juga mengutamakan pembahasan tentang Halal Travel Destination melalui jaringan sosial dalam bentuk komunitas virtual online, dan halhal yang bersifat islami juga lebih diutamakan sehingga wisatawan memiliki berbagai alternative dalam melakukan pengambilan keputusan memilih destinasi wisata halal.

2. Selalu menjaga dan meningkatkan reputasi citra destinasi yang lebih unggul dan mempertahankan pembahasan tentang Halal Travel Destination melalui jaringan sosial dan hal-hal yang bersifat islami sehingga sikap wisatawan dan orientasi keagamaan meningkat dan berdampak kepada keinginan mengunjungi suatu destinasi. 
3. Berdasarkan hasil analisis bahwa variabel Electronic Word of Mouth dan Halal Tourism Islamic tidak bisa berpengaruh terhadap Travel Intention, oleh karenanya diharapkan bagi peneliti selanjutnya untuk mengembangkan penelitian ini dengan mempertimbangkan variabel-variabel lain diluar variabel yang sudah termasuk kedalam variabel ini sehingga menjadi lebih baik lagi.

\section{Daftar Pustaka}

Ashworth, G., \& Kavaratzis, M. (2009). Beyond the logo: Brand management for cities. Brand Management, 16, 520-531.

Rui, H., Liu, Y. and Whinston, A. (2013), "Whose and what chatter matters? The effect of tweets on movie sales", Decision Support Systems, Vol. 55 No. 4, pp. 863-870.

Utama, I Gusti Bagus Rai. 2016. Pengantar Industri Pariwisata. Yogyakarta: Deepublish.

Ye, Q., Law, R., Gu, B. and Chen, W. (2011), "The influence of user-generated content on traveler behavior: an empirical investigation on the effects of e-word-ofmouth to hotel online bookings", Computers in Human Behavior, Vol. 27

\section{JURNAL} No. 2, pp. 634-639.

Abd-Elaziz, Mohammed E., Aziz, Wael M., Khalifa, Gamal S.A., Ma'youf Magdy A.A. 2015. Determinants of Electronic word of mouth (eWOM) influence on hotels customers' purchasing decision. Journal of Faculty of Tourism and Hotels, Fayoum University. 9(2/2) : 194223.

Akbar, Auzan Tawadlu. dan Edriana P. 2017. Peran Kuliner Dalam Meningkatkan Citra Destinasi Pariwisata Taman Nasional Bromo Tengger Semeru. Malang : Universitas Brawijaya.

Battour, M., \& Ismail, M. N. (2014). The role of destination attributes in Islamic tourism. SHS Web of Conferences, 12, 01077. doi:10.1051/shsconf/20141201077.

Battour, M., \& Ismail, M. N. (2016). Halal tourism: Concepts, prac- tises, challenges and future. Tourism Management Perspectives, 19(Part B), 150-154. doi:10.1016/j.tmp.2015.12.008.

Carboni, M., \& Idrissi Janati, M. h. (2016). Halal tourism de facto: A case from Fez. Tourism Management Perspectives, 19, 155-159. doi:10.1016/j.tmp.2015.12.007.
Chu, S.C. and Kim, Y. (2011), "Determinants of consumer engagement in electronic wordof-mouth (eWOM) in social networking sites", International Journal of Advertising, Vol. 30 No. 1, pp. 47-75.

El-Gohary, H. (2016). Halal tourism, is it really Halal? Tourism Management Perspectives, 19(Part B), 124-130. doi:10.1016/j. tmp.2015.12.013. Retrieved from http://www.sciencedirect. com/science/article/pii/S22119736150010 38

Gamble, A., Juliusson, E. A., \& Garling, T. (2009), Consumer attitudes towards switching supplier in three deregulated markets, The Journal of Socio-Economics, $38,814819$.

Hu, X., Ha, L., Mo, S. and Xu, Y. (2014), "Who are fans of Facebook fan pages? An electronic word-of-mouth communication perspective", International Journal of Cyber Society and Education, Vol. 7 No. 2, pp. 125-146.

Iniesta-Bonillo, M. A., Sánchez-Fernández, R., \& Jiménez-Castillo, D. (2016). Sustainability, value, and satisfaction: Model testing and cross-validation in tourist destinations. Journal of Business Research, 69(11), 5002-5007. doi:10.1016/j. jbusres.2016.04.071.

Jalilvand, M. R. \& Samiei, N. (2012), The impact of electronic word of mouth on a tourism destination choice: Testing the the ory of planned behavior (TBP), Internet Research, 22 (5), Forthcoming.

Laksmini, Aditya Ayu Dan Oktafani, F. (2016). Pengaruh Electronic Word Of Mouth (Ewom) Terhadap Minat Beli Followers Instagram. Jurnal Computech \& Bisnis, Vol. 10.

Mohsin, A., Ramli, N., \& Alkhulayfi, B. A. (2016). Halal tourism: Emerging opportunities. Tourism Management Perspectives, 19(Part B), 137-143. doi:10.1016/j.tmp.2015.12.010.

Qu, H., Kim, L. H., and Im, H. H. (2011), “A model of destination branding: Integrating the concepts of the branding and destination image", Tourism Management, 32, 3, 46476.

Rahman, M. (2014). Motivating factors of Islamic tourist's destination loyalty: An empirical investigation in Malaysia. Journal of Tourism and Hospitality Management, 2(1), 63-77. 
Putra, Gagah Bimo Setyo., Kumadji, Srikandi., Dan Hidayat, K. (2015). Pengaruh Citra Perusahaan Terhadap Minat Berkunjung Dan Keputusan Berkunjung. Administrasi Bisnis, Vol. 26..

Wibisono, Nono. dan Eddy Syah. 2016. Persepsi Wisatawan terhadap Daerah Wisata Kabupaten Bandung. Bandung : Politeknik Negeri Bandung.

Zarrad, H and Debabi, M. 2015. Analyzing the Effect of Electronic Word of Mouth on Tourists' Attitude Toward Destination and Travel Intention. National Institute of Applied Sciences and Technology,

Website Univeristy of Carthage: Tunisia.

https://www.cheriatravel.com/2017/11/pengertianwisata-halal.html (diakses pada tanggal 4 agustus 2019 pukul 21.00 WIB).

https://ekonomi.bisnis.com/read/20190813/12/113 5900/ orang-indonesia-makin-hobi-keluar-negeri-defisit-neraca-jasa-punbengkak (diakses pada tanggal 15 agusuts 2019 pada pukul 10.00 WIB).

https://katadata.co.id/infografik/2019/03/05/potens i-besar-wisata-halal\# (diakses pada tanggal 28 Agustus 2019 pukul 19.30 WIB).

https://travel.detik.com/travel-news/d4601471/liburan-ke-eropa-turis-indonesialebih-pilih-wisata-halal (diakses pada tanggal 28 Agustus 2019 pada pukul 22.05 WIB). 